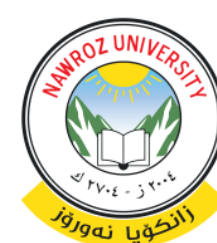

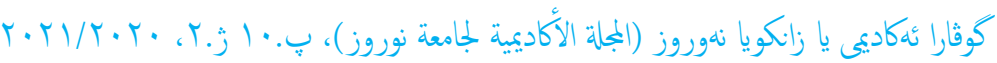

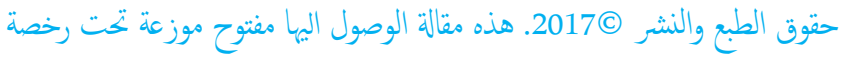

AJ NU

e-ISSN: 2520-789X ،CC BY-NC-ND 4. 0.

https://doi.org/10.25007/ajnu.v10n2a1056

\title{
المحاية الامنية لجواز السفر من الاختراق
}

\author{
نصرالدين سليمان محمد ، مديرية الإقامة، دهوك ، أقليم كوردستان العراق

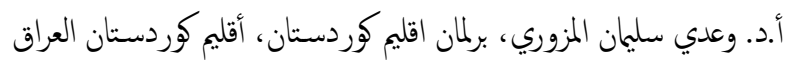

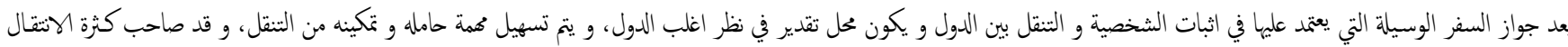

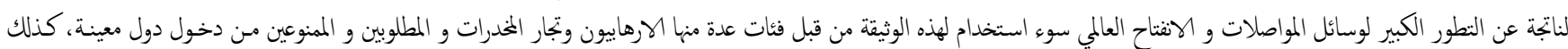

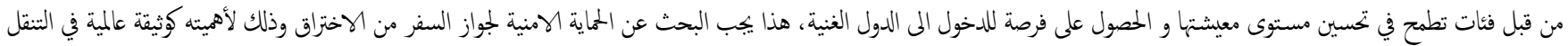

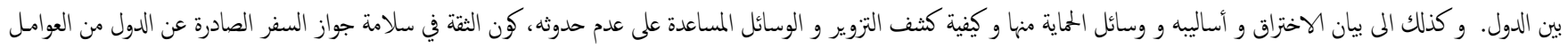

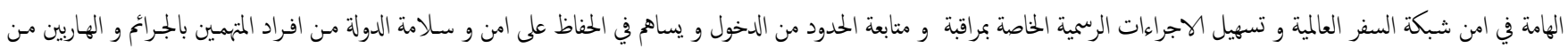

القانون.

الكلمات المفتاحية: جواز السفر، وثائق السفر ، جواز مرور، تزوير جواز السفر.

1

اكتشافها من قبل المختصين في المنافذ الحدودية المختلفة عند قيامم بتنظيم الدخول

\section{والخزوج·}

لذلك أوجبت أنظمة الدول اعلام السلطات المختصة عند فقدان جواز السفر، وتفرض بعض الدول غرامات مالية على فقدان جواز السفر، وأكدت هذه الانظمة بأنه على كل مسافر تسجيل جواز سفره لدى سفارة بلاده في الدول التي يقصد السفر إليها. كل ذلك من أجل المحافظة على جواز السفر باعتباره الوثيقة الأهم في التنقل وخوفاً من سوء استعاله من قبل الغير أو تزويره. وتعتبر جوازات السفر من اكثر الحررات عرضة للتزوير والتلاعب بياناتها لاغراض عدة لذا ترص معظم دول العالم على صناعة جوازات السفر بمواصفات امنية يصعب على الاشخاص العاديين الحصول عليها، وذلك لجعل عمليات التزوير والعبث بها ليست بالسهولة وفي الوقت نفسه تساعد تلك الضانات الموظفين الختصين على اكتشاف التزوير منها وتعد الاوراق التي تطبع بها جوازات السفر من اهم العناصر الداخلة في حاية جوازات السفر من الاختراق. مع تقدم النكنولوجيا لجا المزورون الى استخدام و مواكبة احدث التقنيات للقيام بعمليات العبث والتلاعب والتزوير في جوازات السفر، ولهذا لا بد من وضع صعوبات في وجه من يحاول العبث بجواز السفر حتى يسهل كثف تزويره ويتحقق ذلك بوضع مجموعة من المميزات الدقيقة تبداً من مرحلة تكوين وطباعة المى مرحلة اصداها.
ان تشابك مصاح الناس في المجتمات، وضرورة الانقال من بلد الى آخر وسهولة المواصلات التي يشهدها العالم اليومكل ذلك جعل الجمتمعات في حاجة الى الاعتماد على وثيقة ثبوتية المساة بجواز السفر الذي تصدره الدول طبقاً للقانون، ويكون محل تقدير من قبل الدول الأخرى، ويتم تسهيل تهمة حامله وذلك وفقاً لمبدأ المعاملة بالمثل والعرف الدولي من أجل سهولة الانتقال التي تعتبر حق من حقوق الانسان الهاسية. ونظراً لأهمية جواز السفر كونه محرر رسيم لابد أن يكون له قدسية خاصة بين الأفراد فضلاً عن كون هذه الوثيقة تحدد بعض المراكز القانونية للفرد أمام المجنع الدولي، وخاصة فيا يتعلق باثبات الجنسية وما يترتب على ذلك من حتمية الحصول على تأشيرات دخول لبعض الدول التي تستلزم ذلك بالنسبة لجنسيات معينة أو بالنسبة لتطبيق الاتفاقيات الدولية لتسليم المجرمين. الأمر الذي جعل تزوير الجوازات يزداد بشكل ملحوظ بقصد تضليل السلطات الختصة للوصول الى وضع قانوني، أو تحتيق أهداف معينة ساعد في ذلك تطور وسائل المواصلات السريعة مما أناح المجال لارنكاب العديد من الجرائم ذات الطابع الدولي، وأمكن المجرم أن يرتنكب جريته على أرض دولة ما ثم يسارع بالخروج منها الى دولة أخرى مستخدماً جواز سفر مزور لاخفاء شخصيته الحتيقية التي يكون مطلوباً بموجها، لذلك عمدت الدول على تزويد جوازات السفر بميزات يصعب اختراقها ويسهل 


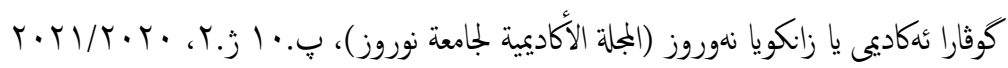

والجواز السفر هو الوسيلة التي يعتمد عليها في جميع دول العالم في مسألة تنظيم

تتبع مشكلة البحث من الاهمية القصوى لجواز السفر وما يجيط بها من مخاطر نتيجة استخداما السئ بصوره الخختلفة، ومدى توفيق الدولة في الحفاظ على جواز

سفرها الاختزاق والحفاظ على امنها وسيادتها وإيجاد سبل كفيلة بحاية جواز السفر وصيانتها من التزوير أو الاستخدام الغير مشروع.

5.1 فرضية البحث

الاليات الحالية بوجب التشريعات النافذة والجوانب الفنية المعتمدة، والامكانيات

الموجودة لدى العاملين في الجهات المختصة لا تتوفر حاية الامنية كافية لجواز

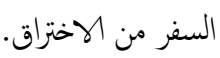

\section{1 نطاق البحث}

يتضمن نطاق البحث على تشريعات العراقية التي صدرت في شان جواز السفر،

مع الاشارة الى بعض التشريعات دول الاخرى كمر وفرنسا في شان جواز

السفر ، وحددنا نطاق البحث على جواز السفر ، رغا ان احكامها ينطبق على

وثائق الاخرى للسفر ، كثيقة السفر او جواز المرور وذلك للاتفاقها مع طبيعة

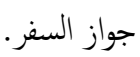

\section{1 خطة البحث}

يتضمن خطة البحث توزيع الدراسة على مبحثين بحيث يضم كل مبحث مطلبين ، وقد خصصنا المبحث الأول لبحث ماهية جواز السفر ، حيث نتناول في المطلب الأول ماهية جواز السفر وفي المطلب الثاني أنواع جواز السفر، اما المبحث الثاني

فقد خصصناه لبحث تامين حاية جواز السفر وقسمنا الى مطلبين تناولنا في المطلب الوول اختراق جواز السفر ، وفي الثاني خصصنا عناصر حاية جواز

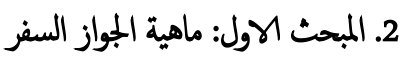

تعتبر جواز السفر الاداة الرئيسية التي يكتقق من خلالها اهم الحريات العامة، وهي التي تمكنه من ممارسة طاقاته البدنية من سكون وحركة التي تتجلى في حرية التنقل، ونظرا لاهمية الجواز السفر باعتبار كونها محرر رسمي ان يكون له قدسية خاصة بين الافراد التي بموجها تحدد بعض المراكز القانونية للفرد فيا يتعلق باثبات الجنسية وما يترتب على ذلك من حتمية الحصول على تاشيرات الدخول التي تلتزم

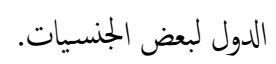

الدخول والحروج عبر المنافذ البرية والبحرية والجوية ويتم من خلال قراءة المعلومات المدونة على جواز السفر مراقبة المشبوهين بالاعمال الاجرامية والممنوعين من السفر والملاحقين أمنياً بالتزوير من أجل تحقيق غاياتهم واخفاء

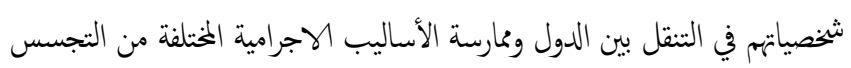

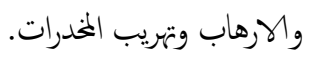

وتعد منافذ الحدود الدرع الواقي لمنع الاشخاص غير المرغوب فيه في الدخول وتناط بموظفي الجوازات فص الجوازات ومن الضروري هنا ان يكون العاملون في منافذ الحدود لديهم تاهيل وتدريب ومهارات وابهزة علمية حديثة تساعدهم على كثف التزوير في الجوازات والتاشيرات. لذلك تسعى الدول الى تحديث جواز السفر الصادرة من سلطاتها، لتكون مؤمنة بالماية الامنية بالقدر الكلفي من محاولات الاختزاق والتزوير، و وضع علامات الامنية بسرية ثامة، وتشديد

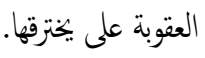

1.1 اهمية البحث

ثكن اهمية البحث في كون جواز السفر المحدد لجنسية الشخص الذي يحملها و هويته في الخارج كما انها يتعرض لعمليات التزوير والاستعالات السيئة بعد احتراقه والعبث والتلاعب بها من قبل الافراد، ونظرا للتطور التقني الهائل في الوقت الحاضر واستعالاته الايهابية والسلبية وانغكاس ذلك على الجواز السفر.

2.1 هدف البحث

يتمثل هدف البحث في معرفة اهية جواز السفر وكذلك التعرف على الانواع الأخرى التي تصدرها الدولة من الجوازات و وثائق السفر سواء للمواطنين او لبعض من الاجانب، اضافة الى عرض خواص صفحاتها الفنية، بهدف نقل معلومات العاملين في المراكز التي تحتك في معاملتها اليومية مع حامل الجواز و وثائق السفر ، بغرض امكانية وسهولة معرفة المخترق منها من السلمة.

3.1

نتبع في كتابة هذا البحث المنهج التحليلى المقارن من خلال تحليل النصوص

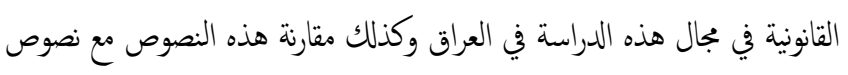
القوانين المقارنة في مصر وفرنسا، اذيقوم هذا المنهج بمساعدة الباحث بتشخيص واقع حهية الامنية لجواز السفر على جوانها المختلقة. 


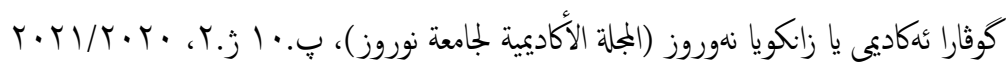

السلطات الوطنية والاجنية وتمكن الشخص بموجبه من عبور المنافذ الداخلية

$$
\text { لبلاده ويكتّه من دخول الدول المصرح له السفر اليها. }
$$

وكثيراً ما يستخدم مصطلح (الباسبورت) في العديد من الدول بدلاً عن جواز السفر ، وقد وجدت هذا المصطلح في قانون العراقي الملني، حيث عرف المثرع العراقي (الباسبورت)(3) بانه: (المستند الذي تصدره الدولة للعراقي لغرض السفر

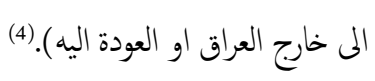

اما بالنسبة لوثيقة السفر فعرفها المشرع العراقي بنص آخر على انه: (المستند الذي تصدر الدولة للسفر المى خارج العراق او العودة اليه في الظروف الاستثنائية).(5) وكذلك بالنسبة لجواز المرور تم تعريفها في التشريع العراقي: (المستند الذي تصدره الدولة للعراقي الذي يفقد جوازه خارج العراق والاجنبي الذي يفقد جوازه في

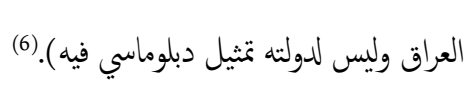

جفواز السفر وثيقة رسمية تعطيها السلطات العراقية لرعاياها الراغبين في مغادرة الاراضي العراقية، او العودة الهيا، وذلك لإثبات هويتهم ازاء السلطات الختصة

$$
\text { سوءاً في دولته ام أي دولة يكون متواجد فيها. }
$$

اما في التشريع المصري نظم القانون رةٌ 97 لسنة 1959 المعدل بالقانون 195 لسنة 2008 الجوازات السفر المصري، فانه لم يضع تعريف محددا لجواز السفر في التشريع المصري، لا انه الفقه عرف جواز السفر بانه: (وثيقة تمنح لمعرفة السلطات الادارية تثبت شخصية وجنسية ومحل اقامة حاملها وتسمح له بالسفر بحرية)(7) ، بنيا يعرفه القضاء بانها: (الصك الذي يتيح للمواطن امكانية مغادرة الاراضي المصرية، وبدونه يستحيل في السفر والتنقل).(8) وكما عرفه المشرع الفرسي في الفقرة الاولى من المادة الخامسة من قانون رقز 2658 لسنة 1945 بانه: (السند المحرر من جانب سلطات دولة الاجنبي ويتضمن الزاميا الهوية الكاملة لصاحبه وصورته وتوقيع وختم السلطة الصادرة عنها ومدة صلاحيته)، (9) وكذلك عرف البعض من الفقهاء في فرنسا بانها: (وثيقة رسمية معترف بها دوليا تصدر من السلطات الختصة في الدولة، من شانها اثبات جنسية

$$
\text { (10). حاملها وشخصيته) }
$$

وعليه نجد من خلال كل النعاريف السابقة أن هناك اتفاق بين التشريعات المختلفة على اعتبار هذه الوثيقة، هي وثيقة رسمية اساسية صادرة من الجهات الختصة في

$$
\text { الدولة بموجها يمنح الحق الكمل بالسفر الى خارج الدولة. }
$$

و يشترط لصحة جواز السفر ان يكون ساري المفعول، ليتمكن حامله من دخول لئل

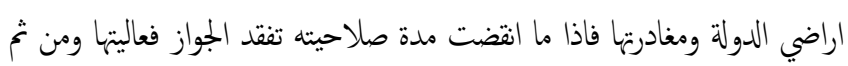

ولذلك نقسم هذه المبحث الى مطلبين نتناول في الاول تعريف جواز السفر وفي الثاني نعرض انواع جوازات السفر في العراق مع الاشارة الى الدول المقارنة.

$$
\text { - - م المطلب المول: تعريف جواز السفر. }
$$

1.2 المطلب الأول : تعريف جواز السفر من المعلوم بحث أي مصطلح أو مفهوم يتطلب أولاً التعرف عليه أي تعريفه وتوضيح ماهيته ليسهل فهمه والبحث فيه وينطبق ذلك على جواز السفر أيضاً، عليه خصصنا هذا المطلب لتعريف جواز السفر في التشريع العراقي والتشريعات المقارنة، دون أن نتعمق في تعريف جواز من كل الجوانب الأخرى وذلك لمحدودية نطاق البحث، ونميز بشيء من الايجاز بينه وبين الوثائق الأخرى، وذلك في

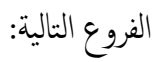

$$
\text { - - - - الفرع الأول: تعريف جواز السفر. - }
$$

1.1.2 الفرع الأول: تعريف جواز السفر

ان جواز السفر هو وثيقة تصدرها حكومة دولة إلى مواطنيها بعد التحقق من هوية وجنسية حامله بغرض السفر الى خارج دولته، و هو عبارة عن كنيبات صغيرة تحتوي عادةً على اسم حاملها ومكان الميلاد وتاريخ الميلاد وتاريخ الإصدار وتاريخ اتهناء الصلاحية ورق جواز السفر والصورة والتوقيع. ويعرف بجواز السفر لغةً بانه: (وثيقة تمنحها الدولة لاحد رعاياها لإثبات شخصيته

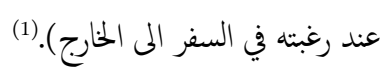
اما قانونا فيعرف جواز السفر في القانوذي العراقي بانه: (المستند الذي تصدره الدولة للعراقي لغرض السفر المى خارج العراق او العودة اليه).(2) عليه فإن جواز السفر وثيقة تصدر من السلطات الرسمية المختصة في دولة لحامله، ويعد جواز السفر Passport اقوى وثيقة رسمية يكن ان يستدل بها على الحلالة

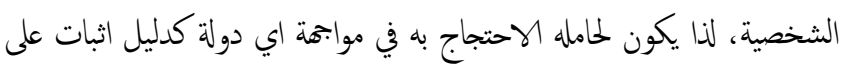
شخصيته. ويحتج بجواز السفر كوثيقة اثبات شخصية بين الدول فهو الوثيقة التي تصدرها

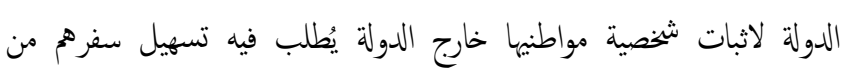




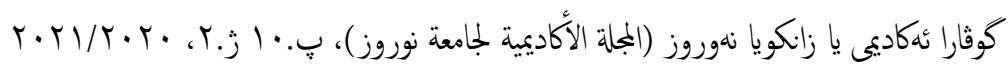

اصدار الجواز او سهبه او الغائه، ولا يخضع لاي رقابة قضائية ولا يتزتب عليه اي مسؤولية ادارية، حيث يتمتع الوزير بسلطة تقديرية كبيرة في هذا الصدد وان كان يكن لصاحب الشان التظلم للجهة مصدرة القرار.(14)

ومن الجدير بالذكر، ان اول جواز سفر بريطاني صدر في 1914/1/18، وكان موقع من الملك تشارلز ، وتطورت عملية اصدار جوازات السفر بريطانيا، حيث كان في البداية توقع كل جوازات السفر من الملك شخصيا ثخ اصبحت بعد ذلك تصدر بواسطة سلطات الدولة، وكان هناك نوعان من الجوازات حتى عام 1794، الاول جواز فاخر يوقع عليه الملك شخصي، والثاني موقع من سلطات الدولة ولكنه

صادر باسم الملك. (15) - مانك

ويعتبر الجواز السفر يعتبر قرينة على تمتع حامله بجنسية الدولة التي اصدرته، فان هذه القرينة تقبل اثبات العكس. فني العراق وكما هو مستقر ان شهادة الميلاد او هوية احوال المدنية، او بطاقة التموينة، لا تثبت الجنسية العراقية، لانها ليست معدة لاثباتها كما انها لا تعتبر دليلا كافيا على ثبوت الجنسية، وقد يكون هذه هي المستندات الاساسية التي يتم على اساسها استخراج جواز السفر. ونظرا لاهمية جواز السفر كنها محرر رسمي، يجب ان يكون له قدسية خاصة بين الافراد، بالاضافة الى ان جواز السفر تحدد بعض المراكز القانونية للفرد امام المجتمع الدولي، وبالاخص فيا يتعلق باثبات الجنسية، وما يترتب على ذلك من حتمية الحصول على تاشيرات الدخول لبعض الدول، وقد يلجا بعض الافراد باستخراج

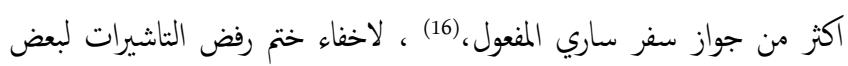
السفارات عند تقدمم لها، للحصول على تاشيرات دخول لبعض الدول او للحصول على اكثر من تاشيرة دخول لبعض الدول في نفس الوقت، او لاخفاء

$$
\text { بعض البيانات باستخراج جواز سفر جديد.(17) }
$$

ويرى الباحث ان استخراج اكثر من جواز سفر عادي لا تشكل جريمة يعاقب عليها القانون طالما ان البيانات الخاصة باستخراج جواز السفر صحيحة، وعملية استخراج اكثر من جواز سفر عادي صالخ في ذات الوقت قد يكون له اكثر من فائدة عملية، حيث قد يضطر الشخص لاستخراج اكثر من جواز سفر في حلات تقديم جواز سفره كستند في جحة قضائية او ادارية، او وجود جواز السفر باحدى السفارات الاجنبية للحصول على تاشيرات هذه الدول، وقد تجد ظروف طارئة تستلزم سفر صاحب الجواز في الحال كظروف صحية عاجلة. وعادتا تصدر الدولة جواز السفر من سلطة وطنية لم تحصل على استقلالها بعد، مثل وثيقة السفر التي تمنح للعراقيين(18) والصادر من السلطة الائتلاف المؤقتة
لا تعتد الدولة به مالم يمدد لمرة اخرى او يجدد كما استلزم القانون لصحة جواز السفر ان يكون صادرا من السلطات الخختصة بإصداره وعادة ما تكون وزارة الداخلية هي الجهة المعنية بذلك.(11)

\subsection{2 الفع الثاني: أساس منح جواز السفر}

يختلف الدول في صرف جواز السفر للمواطنيها باختلاف معاملتها لمواطنيها، وان الاصل الو يمنح جواز السفر الم لمواطني الدولة، و لاييوز منحه للاجانب ، وبتالي لا يصدر الجواز الا بعد التحقق من جنسية طالبه، سواء من خلال تقديمه شهادة جنسية العراقية او البطاقة الوطنية، كما هو في العراق، او البطاقة الشخصية او العائلية كما هو الحال في مصر وفرنسا، او من خلال شهادة الميلاد بالنسبة للدول التي تاخذ بمبدأ الجنسية مثل انجلترا، الهان الدول قد تقوم بصرف جوازات السفر المى بعض الافراد الذين ليسوا من جنسيتها، مثل قيام بعض الدول بصرف جوازات سفر لرعايا البلاد الخاضعة لمايتها، او تقوم بصرف جوازات سفر لبعض الاجانب الذين ليسوا من رعاياها مثل الجوازات والوثائق التي تمنح للاجئين وعديم الجنسية.(12) كما سوف نرى لاحقا. اي ان جواز السفر هو وثيقة تصدر من الدولة لكل من يحمل جنسيتها لمدة محددة تمكنه من دخول الى الدول او الانقال بين الدول، ومن غير المقبول بطبيعة ان

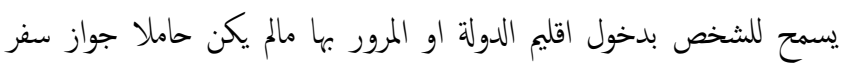
قانوني، اذ يعتبر هذا الجواز كضابط يتحكم اليه في تحديد صفة حامله.(13) ويثور التساؤل في هذا الجانب عا اذا كان جواز السفر حقا للمواطن ام منحه من الدولة؟ وعند البحث على الاجابة على هذا التساؤل انه يختلف باختلاف الدول واسلوب معاملتها لمواطنيها عند صرف جوازات السفر لمم فبعض الدول تعتبره منحه من الدولة، وغالبا الدول التي لا ترغب في هرة سكانها الو بشروط معنية، لافتقارها المى السكان، اما بعض الاخرى يرى بانه حق للمواطن استنادا الى حرية التنقل، كما هو موجود في العراق. the prerogative Power فني انكلترا يعتبر جواز السفر ملك للناج الملكي وامتياز من امتيازاته، رغ ان حرية السفر والتنقل تعتبر من الحريات الاساسية للمواطن البريطاني، ويشترط حصوله على جواز سفر حتى يتمن من مغادرة اراضيها، وتصدر جوازات السفر عن طريق وزارة الشئون الخارجية والكومنولث بموجب امتياز الناج، وتظل ملكا للناج رغز اصدارها وتسليها المى صاحها ويجوز لوزير الثؤون الخارجية والكومنولث المنوط به اصدار جوازات السفر رفض 


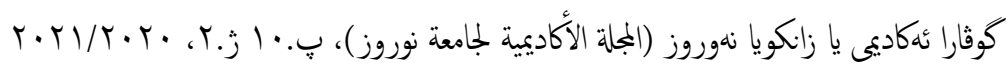

المعاملة لأشخاص تولوا في الماضي وظائف دبلوماسية عالية، كرؤساء الدول ورؤساء الوزارة ووزراء الخارجية والسفراء وافراد عائلاتهم وذلك لتسهيل امورهم

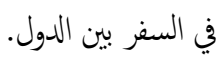
وفي الوقت الحالي يفرض التعامل الدولي قيام كل دولة بإرسال ممثلين عنها الى الدول الاخرى، وهو اعضاء السلك الدبلوماسي والقنصلي، وتكون تهمتهم رعاية مصالحها والقيام بشؤون رعاياها في الخارج، وكذلك تنمية التعاون بين دولته والدول الوفدين الهيا في ختتلف المجالات العلمية والاقتصادية والثقافية والسياسية

ومن الطبيعي ان يتولى هذا العمل افراد ذو مؤهلات ومواصفات معينة. ومن الجدير بالذكر ان الغاية من منح الجواز الدبلوماسي هو لتسهيل اداء الوظيفة الدبلوماسية، ويكون الاختصاص اصدار جواز السفر الدبلوماسي من صلاحية وزير الخارجية حصرا، حيث ان الاصل تتولى وزارة الخارجية اصدار وتجديد جوازات السفر الدبلوماسي،21(21من اجل ذلك اعطي صلاحية لوزير الخارجية منح جواز السفر الدبلوماسي لحامل البريد السياسي، لمن نكلفه وزارة الخارجية بحمل هذا البريد الى خارجه وبالعكس، خدمة لمهامه الوظيفي، ولتسهيل تنقلهم خلال عملهم يمنح لم جوازات سفر دبلوماسية ويمتد ذلك ليشمل افراد اسره

$$
\text { المرافقين لم. (22) }
$$

وفي العراق لوزير الخارجية منح جواز سفر دبلوماسي لمن يقوم همة تتعلق بسلامة الدولة ومصالحها العليا، ويقدر الوزير ذلك وفق ما تمليه ضرورات ومصاح امن الدولة ومصالحها، وكذلك المشرع المصري الى انه يجوز بناء على طلب وزير اللاخلية منح جواز سفر دبلوماسي لمن يقوم بهمة تتعلق بسلامة الدولة مصالحها الوطنية العليا(23). وفيا يختص بمنحها وتجديدها هي وزارة الخارجية

$$
\text { لمهورية مصر. }
$$

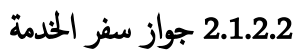

تجد ان مرتبة هذا النوع من الجواز تأتي بعد الجواز السفر الدبلوماسي، ويسمى هذا الجواز في بعض الدول بجوازات السفر الخاصة او الرسمية، ويمح لطائفة من الاشخاص الذين يشغلون مناصب رفيعة في الدولة، الذين لا يحق لم بحمل جوازات دبلوماسية لعدم قياهم بهام دبلوماسية، ولم يصلوا الى درجة منحهم جواز السفر الدبلوماسي، وبالرغ من اختلاف مناصب هذه الفئات المختلفة،

ومكانته الخاصة في المجتع..24) باسم الحكومة العراقية، في فترة مجلس الحكم العراقي المؤقت في العراق، وكذلك الحال بالنسبة لجواز السفر الصادر من السلطة الوطنية الفلسطينية ويمنح للفلسطينين التابعين تحت الاحتلال الاسرائيلي، وفقا لاتفاقية غزة - اريحا، وبموجها يمق اصدار جواز سفر باسم السلطة الفلسطينية. (19) ومن جانب آخر قد يصدر جواز سفر من احدى المنظات الدولية للعاملين بها مع احتفاظ كل منهم بجنسية وجواز سفره الصادر من دولته الاصلية، كالجوازات الصادرة من منظمة الام المتحدة لموظفيها والعاملين فهيا. وهناك حالة أخرى قد يستبدل جواز السفر بوثيقة لها ذات الطبيعة نسها وتمنحها لطائفة معينة من الاجانب ولا يكنها الحصول على جواز سفر ولا يجدون اي دولة، او سلطة وطنية يخاطونها للحصول على جواز السفر مثل عديم الجنسية Apatrides واللاجئين Refugies ، كما سوف نرى لاحقا.

2.2 المطلب الثاني: أنواع جواز السفر

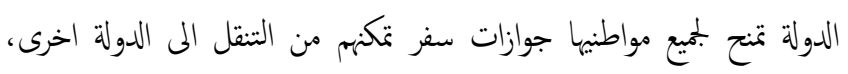
وتحدد كل دولة انواع ومواصفات وفق شروط واليات معينة لإصدارها، ونجد ان غالبية التشريعات الحديثة ترص على عدم جواز ادخال الاجنبي اقليم دولتها ما لم يكن حاملا لجواز سفر صادر من السلطات الختصة في دولنه، وفقا لذلك تمنح الدولة كذلك لمواطنيها جواز السفر بعد استيفاء الشروط الضرورية من حيث الشكل والبيانات، و هناك بموعة يوجد شبه اتفاق عليها بين الدول وهناك بمموعة أخرى لكل دولة لها سياقها الخاص بها في تحديدها لذلك عليه نتناول في هذا المطلب أنواع جواز السفر وغرض كل نوع وفق التفصيل في الفروع التالية:

$$
\text { - - - - الفرع الأول : جوازات السفر الوطنيين. }
$$

تنص المادة الثانية / اولا من قانون الجوازات النافذ رق 32 لسنة 2015 على ان: يكون جواز السفر على اربعة انواع: (دبلوماسي، خاص، خدمة، عادي). ومن هذه الأنواع من الجوازات الآتي:-

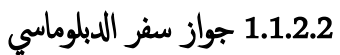

الاصل ان جواز السفر الدبلوماسي لا يمنح لمجيع المواطنين، وانما لأفراد يشغلون مناصب معينة تنميزها بأهميها، ويبدو ان منح هذه الفئات جوازات دبلوماسية ما هي الا استثناء، حيث يتم فهيا منح هذه النوعية من الجوازات على اساس 


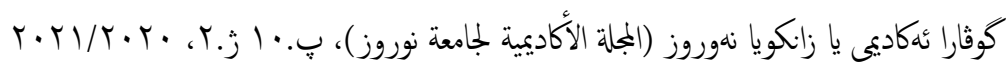

للاول التي تأخذ بمبدأ الجنسية مثل مملكة المتحدة البريطانية.(26) وييدو ان المثرع العراقي والمصري والفرسي يتفقون على اصدار جوازات السفر العادية والدبلوماسية، فانهم يختلفون في تنظيم الانواع الاخرى ومن هذه الأنواع هي (27):-

\section{Refugees 1.2.2 اللاجثون}

ان المادة 28 من اتفاقية الام المتحدة الخاص للاجئين (28)، تنص على انه (تصدر الدول الموقعة للاجئين الموجودين بصورة مشروعة على اراضيها، وثائق سفر لغرض السفر للخارج، مالم يتعارض ذلك مع اسباب ملحقة تتعلق بالأمن الوطني

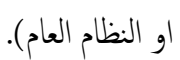

وتمنح هذه الوثائق المى اللاجئين تحت اشراف مكتب الوم المتحدة لشئون اللاجئين، وبالتنسيق مع وزارة الخارجية بالدولة المتواجد بها اللاجئ، كما ويقرر ملحق الاتفاقية الخاصة باللاجئين التابعة للأم المتحدة شروط الشكل والطريقة لاستخراج الوثيقة بحيث يكون نموذج موحد في دول العالم كافة، التي وقعت على

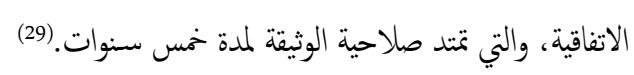

وقد صدر في العراق قانونا للاجئين، ويسمى بقانون اللاجئين السياسيين في العراق رقّ 51 لسنة 1971، (30) وموجب هذا القانون، بعد الموافقة على طلب اللجوء الاجنبي تتولى وزارة الداخلية بمنح وثائق السفر الى اللاجئين وزوجاتهم واولاده)، ومن الملاحظ ان المثرع اشار المى وثائق السفر الصادرة لبعض فئات

$$
\text { الاجانب، ويسمى جواز مرور. (31) }
$$

والحال في مصر تمنح وزارة اللاخلية وثائق السفر الى اللاجئين وعوائلهم والتي يعيلهم اللاجئ قانونا، وكذلك في فرنسا فانه في حالة موافقة السلطات المختصة على ورلى

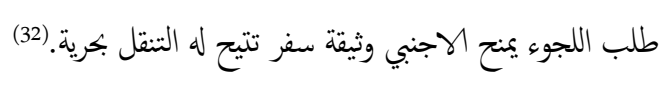

\section{Apatrides 2.2.2 عديمي الجنسية}

عديمي الجنسية هم الاشخاص الذين لايحملون جنسية اي دولة، وتحدد اوضاعهم اتفاقية نيويورك لسنة 1985، وعادة تقدم الدولة للأشخاص الذين ليست لم جنسية معينة تسهيلات و مزايا وذلك لمراعات أوضاعهم وظروفهم الخاصة، ومنها منح وثائق السفر، ونجد ان عديموا الجنسية واللاجئين تجمعهم عادة وحدة الشقاء

$$
\text { في ظروف حياتهم المعيشية وتنقلهم. (33) }
$$

ان الجمتع الدولي اخذ هذه المسالة بكثير من الاهتمام، فبذلت بجمود خاصة على مستوى المنظات الدولية التي ابرمت اتفاقية وقع عليها في جنيف سنة 1933 تلتزم الدول الموقعة عليها بمنح عديم الجنسية جواز سفر خاص يسمى (نانسن)، (34) كما استقرت الدول الحديثة على وجوب استخراج وثيقة بديلة لجواز
وتتمتع حامل جواز السفر الخدمة بعض المزايا، اله انها تقل عن تلك المزايا التي يتمتع بها حامل جواز السفر الدبلوماسي فعلى سبيل المثال لا يعفي من قيود التزخيص بالإقامة في البلد الذي يذهب اليه وان كان يعني من الحصول على تأثيرة الدخول لتلك الدولة، او يمنح تأشيرة دخول خاصة طبقا لمبدأ المعاملة بالمثل.(25) ويبدو ان غاية من هذا الجواز ابراز وظيفة حامله بجيث تقوم الدولة الاجنبية بمراعات وضعه وتقديم بعض التسهيلات الاضافية له على سبيل المجاملة، والمعاملة بالمثل.

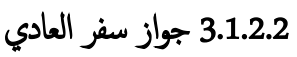
ان هذه الجواز هي الاكتز شيوعا واستعلال، وهو الجواز الذي يصدر لكافة المواطنين الراغبين بالحصول عليها بعد استيفاء الشروط المطلوبة، وتتولى كل دولة تحديد شكلها ومواصفاتها ويمنح هذا الجواز وفقا لشروط معينة حددها القانون العراقي وصورها كانت تحمل احد الاحرف الاتية (N, H, S, G, A) ورائها

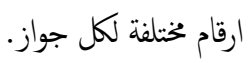
وللجهة المختصة بمنحا وتجديدها في العراق هي وزارة الداخلية وتمنح جوازات السفر العادي لأشخاص العاديين بالنسبة لمدة صلاحية الجواز السفر العادي، ففي العراق هو ثمانية سنوات من تاريخ صدوره ولا يجوز مد صلاحيته بعد انتهاء هذه المدة، ويلزم باستخراج جواز جديد بثانية سنوات أخرى، اما بالنسبة للاولاد القاصرين التي تكون المدة صلاحية الجواز هي اربعة سنوات، وفي جمهورية مصر فان مدة صلاحية الجواز هي سبعة سنوات من تاريخ صدوره

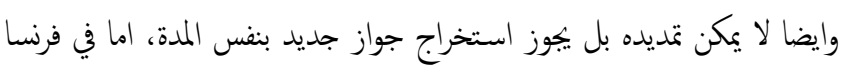
فان صلاحية جواز السفر عشر سنوات بالنسبة لعموم الفرنسين من غير الوالاد

$$
\text { القاصرين التي تكون مدة صلاحية الجواز هي خمس سنوات. }
$$
ومن الجدير بالذكر ان قانون الجوازات السفر العراقي رقّ 32 لسنة 2015 النافذ، اضيف الى انواع الجوازات التي اشرنا اليه سابقا بنوع اخر وهو جواز سفر (الخاص) حيث لم يكن هذا النوع من الجواز موجودا في القوانين السابقة، اله انها لم يمحد الاشخاص المستحقين لهذه الفئة من الجواز.

2.2.2 الفرع الثاني: جوازات السفر لغير الوطنيين. ان الاصل لا يمنح جواز السفر الم لمواطني الدولة، ولا يجوز منحها للأجانب وبتالي لا يصدر الجواز الV بعد التحقق من جنسية طالبة سواء من خلال تقديم البطاقة الوطنية او الجنسية العراقية كما هو الحال في العراق، و بطاقة الشخصية او العائلة كما هو الحال في مصر وفرنسا، و من خلال شهادات الميلاد بالنسبة 


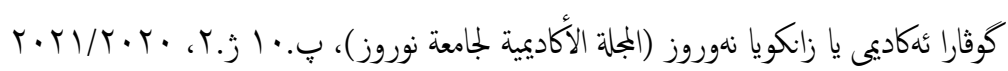

\subsection{2 وثاثق سفر اللاجئن الفلسطينيين}

تقوم العراق بإصدار وثائق سفر الى اللاجئين الفلسطينين، المقيمين عادة في العراق، (42)(المشمولين برعاية الحكومة العراقية، وتصدر هذه الوثيقة بصورة استثنائية بعد موافقة وزارة الداخلية الى اللاجئين الفلسطينيين المتميين في العراق. وحيث تختص باصدار هذه الوثيقة مديرية الجوازات العامة، وتمند صلاحيتها الى خمسة سنوات من تاريخ اصدارها استنادا الى المادة السادسة/ أ من النظام 26

لسنة 1961) - (43).

وتجدر الاشارة تمنح العراق تسهيلات عديدة في مجال الحصول على الجواز السفر بدون مقابل في مجال الدخول والاقامة وكذلك نفس الحال في مصر. واخيراً ستخلص مما تقدم لكي يتتع الشخص بجقه في السفر والتنقل يستلزم ان يحصل على وثيقة رسمية تثبت شخصيته وتصدر من الدولة التي يحمل جنسيتها او اي سلطة اخرى معترف بها، وتتيح لحاملها الثنقل والمرور بين الدول وهذه الوثيقة يككن ان نطلق عليها جواز السفر، وهي تعتبر في الوقت الراهن من متطلبات الاساسية لمغادرة الوطن والسفر من دولة المى اخرى بالرغ من اختلاف انواعها فضلا عن كنها وثيقة اثبات للشخصية، صادرة عن دولة الشخص الاصلية واثباتا لانتائه لها، كما انها وثيقة تثبت على امكانية عودة حاملها المى وطنه، وبذلك يكون جواز السفر عبارة عن الاداة التي تمكن الشخص من ممارسة حقه في التنقل بين

\section{3. المبحث الثاني: تامين حاية جواز السفر}

يقصد بتامين حاية جواز السفر هو حايتها من التزوير، وذلك بوضع عقبات و صعوبات في طريق كل من يحاول اختراقها، بجيث يسهل كثف هذا الاختراق في جواز المخترق وظهور اختلاف واضحة بين الصحيحة، والاخرى المخترقة. ويلجا الشخص عادة المى الاختراق جواز السفر لتحقيق منفعة لمم من استعال جواز المخترق. ويتم حاية جواز السفر باعتماد خصائص واضحة في دفتر الجواز، بجيث يصعب تقليدها و وضع مجموعة من الاشارات ذات مميزات فريدة وحساسة يصعب تقليدها، ويتغير مظهرها عند محاولة العبث بها. ان جريمة التزوير بشكل عام من الجرائم الخطرة التي انتشرت في دول العالم، لذل فهي تهد استقرار الثقة العامة في المحررات الرسمية وتخل في المعاملات وسائر مظاهر الحياة القانونية في الجمتع، والتزوير هو الباس الباطل ثوب الحت مما يؤدي الى تغيير الحقيقة واضطراب في التعامل لدى الافراد، وجرائم التزوير من الجرائم
السفر خاصة لعديم الجنسية تصدر من الدولة المتوطنين فيها او المقميين بها اقامة دائمة تمكنه من الانتقال والسفر بين الدول المختلفة ودخول اية دولة من الدول الاجنبية بمقتضى وصفهم الثابت في تلك الوثيقة. (35) وعلى هذا الاساس نجد ان المادة 10 قد أجلازت في نظام جوازات السفر رق 61 لسنة 1959، اصدار وثيقة السفر للأشخاص عديي الجنسية الذين لا ينتمون الى اية دولة، وتكون مدتها سنة واحدة.(36) وييدو ان الدولة عادة تقدم للاشخاص الذين ليست لمم جنسية معينة هذه التيسيرات والمزايا مراعاة لظروفهم الخاصة. وفي مصر كذلك تنح وثيقة السفر لعديي الجنسية وهو الذي لا ينتسب الى اي دولة وكذلك الحال بنسبة لزوجته واولاده.(37) وللأجانب عديمي الجنسية في فرنسا حق التقدم للسلطات بطلب للحصول على وثيقة للسفر ، وبعد الموافقة تقوم المديرية المختصة بإصدار وثيقة سفر للأجنبي حسب محل اقامته، وتكون الوثيقة صالحة لمدة عامين قاباة للتجديد.38)

\subsubsection{3.انب غيز القادرين الحصول على جواز سفر:}

ان هذه الفئة من الاجانب المنتمين لدولة معينة وليسوا بلاجئين و لاعديو الجنسية في الدولة المقيمين او المتوطنين فيها، ولكن قد يتواجدون في الدولة لأي سبب كالسياحة او الدراسة، وتنتهي او تنقد جوازات سفرهم، ويستحيل عليهم الحصول على وثائق سفر الدول التي ينتمون الهيا، كان تكون دولتهم في حالة حرب، او بها كارثة طبيعية تمنح سلطات الدولة من مارسة نشاطها، وكذلك الاجانب المولودون في الدولة، ويتعذر عليهم استخراج جوازات سفر من بلادهم الاصلية لأي ظرف من الظروف، وفي اغلب الدول تصدر هذه الوثائق للأجانب الذين يتواجدون في ذات الظروف، وتكون صالحة للخروج من البلاد فقط دون العودة اليها.(39)

ونجد ان المثرع العراقي قد عاج هذه المسالة بهدف منح هذه الوثائق ميزة لتسهيلات لهذه الفئة من الطوائف من الاجانب مع الاختلاف في التسمية، وذلك استنادا الى المادة (1/ثانيا)(40) من قانون الاقامة النافذ، وذلك بنح هؤلاء الاجانب جوازات المرور، حيث يسمح للأجنبي الذي دخل اراضي جمهورية العراق بصورة مشروعة وقد فقد او تلف جواز او وثيقة سفره ولم يكن لدولته تثثيل دبلوماسي داخل العراق، اذن هذه الوثائق تمنح لهذه الفئات من الاجانب من قبل دائرة الاقامة مؤقتة مجانا لغرض مغادرة الاقليم والعودة الى بلادهم الاصلية دون العودة.(411) 


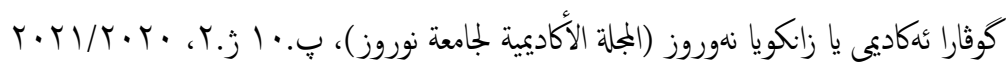

اما الفقه عرف المحرر بانه: (هو المحرر الني يحرره موظف عام او مكلف بخدمة

عامة او ينسب صدوره المى موظف عام مختص بتحريره).(45)

و تغيير الحقيقة يمل جوهر التزوير الذي هو عبارة عن كذب مكتوب، وهو لا يكون متصورا بغير ابدال الحتيقة بما يخالفها، وحيث لا يخصل تغيير للحقيقة فلا يقع التزوير، ولا بد ان يقع تزوير الحتيقة في سند او وثيقة او اي محرر اخر، واذا

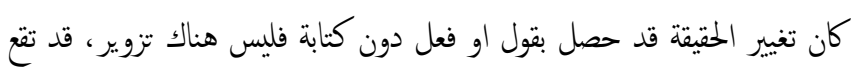

$$
\text { جريمة اخرى كشهادة زور او الححتيال. }
$$

كما بينا ان المحرر الرسمي في موضوعنا هو "جواز السفر"، وان اساليب تزوير جواز السفر اما ان يكون التزوير المادي: هو كل تغيير ينال جواز السفر بطريقة مادية، بجيث يترك أثراً تدركه العين المجردة أو يككن كثفه بالوسائل العلمية

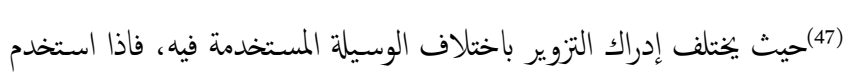
المزور الاسلوب العلمي واتقن عمله قد لا يكشف بسهولة، واذا استخدم الأساليب البسيطة كان عرضة للكشف.

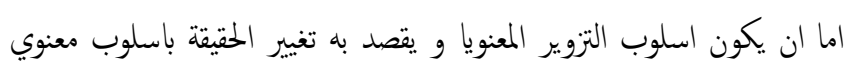
ليس فيه تدخل مادي اي ان التزوير لا يصيب جواز السفر في مظهره وانما في مضمونه ابتداء عند الكتابة ويكون مصدره الشخص المكلف بالكتابة فيقوم باثبات ما يخالف الحقيقة كأن يثّت اسم صاحب الجواز قاسم بينا اسمه الحتيقي جاسم

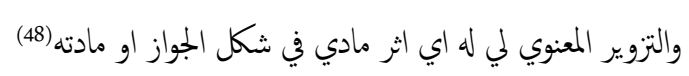

يقع التزوير المادي والمعنوي في البيانات جواز السفر و على بيانات الشخصية ويشمل البيانات الشخصية (اسم حامل الوثيقة، الصورة الشخصية، مكان وتاريخ الميلاد، المهنة والعنوان او التوقيع الوثيقة، او علامات او ميزات فردية)، وكذلك يقع على بيانات تنظمية: ويشمل (رقّ الوثيقة، جهة وتاريخ اصدار، مدة الصلاحية، اختام الاصدار والصورة، توقيع جهة الاصدار، اختام التجديدات ،

$$
\text { اختام تاشيرات الدخول والخروج). }
$$

ويتم كثف التزوير المادي في جوازات السفر عن طريق العين الحبيرة المدربة وكذا باستخدام الادوات والالات الفنية المساعدة طبقا لنوع وطريقة التزوير المستخدم، ويجب بدأوة فص الجواز بعد تكبيره تكبيرا بسيطا تحت اضاءة جانية واضاءة متحلحلة بحثا عن مناطق ينفذ فيها الضوء اكثر من غيرها، او مناطق تركت فيها مسافات فاصلة بين الحروف والكلمات اكبر او اقل من المعتاد او

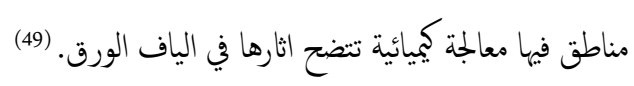

الخطرة لما فيها من عدوان على سلطات الدولة، واعتداء على مصالحها المادية، والاضرار بمصالح الافراد والثقة العامة(44)، ويعد التزوير في الجوازات من الجرائم الثائعة في العالم. وعلى ذلك نتناول في هذا المبحث تامين جواز السفر - - مالمطلب الاول: اختراق جواز السفر - - م المطلب الثاني: عناصر ثامين جواز السفر

1.3 المطلب الاول: اختراق جواز السفر ان مسالة تامين جواز السفر لا يقل اهمية عن امر تنظميه، ولماكان جواز السفر ، هي الصك الرسمي لمارسة حق السفر والتنقل، ومع تزايد المضطرد في تزوير جواز السفر وابتكار اساليب جديدة ومتطورة و المتّاح في جرائم تزوير. عليه نتسم هذه المطلب المى فرعين تنناول في الوول تعريف الاختراق "التزوير" والثاني نخص

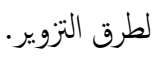

$$
\text { - - - - الفرع الاول: تعريف التزوير "الاختاق" }
$$

\subsection{3 الفرع الاول: تعريف التزوير "الاختراق"}

الاختراق في موضوع بثثنا هو التزوير والتي تقع على المحررات الرسمية- جواز السفر- ، ينقسم التزوير في المحرات الى نوعين ها التزوير المعنوي والتزوير المادي والاختلاف بينها يكمن في ان التزوير المعنوي لا يترك اثرا ماديا ملموسا في المحرر تدركه العين المجردة بعكس التزوير المادي الذي يترك اثرا ماديا يمكن ملاحظته او اكتشافه، والتزوير المعنوي يحدث عن طريق الادلاء بمعلومات غير صحيحة للموظف في جهة رسمية او عن طريق تقديم مستندات مزورة يتم بناء

$$
\text { عليها اصدار المحرر المزور تزويرا معنويا. }
$$

عرفت المشرع العراقي التزوير في نص المادة 286 من قانون العقوبات رق 111 لسنة 1969 المعدل على انه: (التزوير هو تغيير الحقيقة بقصد الغش في سند او وثيقة او اي محرر اخر باحدى الطرق المادية والمعنوية التي بينها القانون، تغييرا من شانه احداث ضرر بالمصلحة العامة او بشخص من الاشخاص). وقد عرف المشرع العراقي في المادة (288) من قانون عقوبات المحرر الرسمي بانه: (هو الذي يثبت فيه موظف او مكلف بخدمة عامة ما تم على يديه او تلقاه من ذوي الشأن طبقا للاوضاع القانونية وفي حدود سلطنه واختصاصه او تدخل في تحريره على اية صورة او تدخل باعطاء الصفة الرسمية). 


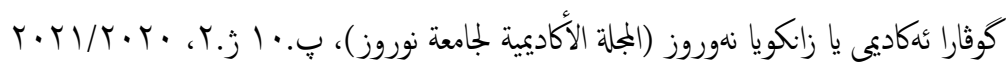

بمحاولة تقليد ومحاكة معظم المميزات والعلامات التي تظهر بالعين المجرد، ودقة التزوير بهذه الطريقة تجعل همة الكشف عنه صعبة ودقيقة، ولكن بامعان التدقيق تكشف عن اختلافات في التصميم او العلامات المائية او السرية وهو ما يقتضي

الا يقتصر الفحص في مراكز الحدود والمطارات والمؤاني المختلفة. (53)

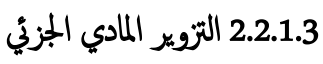

ويتم اختزاق وثائق السفر عن طريق التزوير المادي الجزئي باحدى الوسائل

الاتية:- (54)

\section{التوبر بالتغيير والتحريف وذلك باستخدام وسيلة الحك او الشطب:}

أ. المحو الالي: ويتم بالكشط او الحك ويستخدم المحو الالي في محو

البيانات التي تشغل حيزا صغيرا في الحررات او المستندات مثل

الارقام والحروف وتستخدم ايضا هي الممحاة وذلك في حالة اذا كانت

الكنابة المراد محوها تشغل مساحة اكبر مثل العبارات والجمل. ب. المحو الكيائي: عبارة عن استخدام محاليل كيائية خاصة لازالة مساحة كيرة من الكنابات على المستندات او المحررات حيث تنفاعل المحاليل مع مواد الكنابة كيميائيا واخفائها عن العين المجردة. ج. ازالة الصورة: وذلك بنزع الصورة الاصلية واستبدالها بصورة اخرى. التزوير بالاضافة: عبارة عن اضافة بيانات مكان البيانات التي تمت ازالها عن طريق المحو او بيانات اضافية عن طريق التحشير بين سطور المحرر والهوامش او الفراغات الموجودة بالمحرر، اضافة الى وضع امضاءات او

$$
\text { اختمام مزورة ونسبتها الى شخص اخر دون علمه ورضاه. }
$$

التوير بالاتلاف: وتتم هذه الطريقة عن طريق اتلاف جزء من المستند او الوثيقة او اتلافها كليا لاخفاء بعض البيانات بغرض التزوير.

التجميع: وهو يتم بتجميع اجزاء من النصوص من جوازات اصلية لاستخراج صورة اصلية مصطنعة ثم تصويرها لتحويلها الى ورقة متحدة وتنقل على الحجر الطباعي مع استعال مواد ملائمة لنقلها، ومن السهل اكتشاف تزويرها بالعين المجردة من خلال ملاحظة الاجزاء الاصطناعية

التي يضطر اليها المزور والتي تتضح بواسطة الميكروسكوب المكبر.(55)

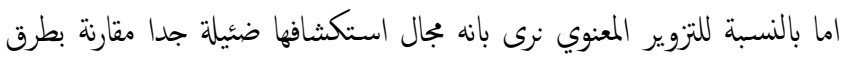
التزوير المادي لكونه لا يترك اثرا ماديا ملموسا في جواز السفر يككن تدركه بالعين

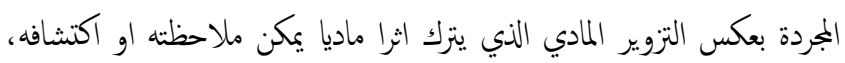

2.1.3 الفرع الثاني: طرق التزوير "اختراق"

ينقسم التزوير المادي الى قسمين الوول التزوير الكلي: هو عبارة عن اصطناع مستند او محرر بالكمل عن طريق التقليد او المحاكة بحيث يكون مشاها للمستند الصحيح في صفاته من حيث الورق والمظهر الخارجي والداخلي وهو من اخطر انواع التزوير كونه يصدر من جهة غير رسمية لدهيا الامكانيات المادية والفنية لاصدار المستندات والمحررات المزورة تزويرا كليا. والثاني التزوير المادي الجزئي: فهو احداث تنييرات بطريقة غير مشروعة بالمحررات او المستندات باحدى طرق التزوير المادي الجزئي بعد صدور المستند او الوثيقة، على عكس التزوير المعنوي

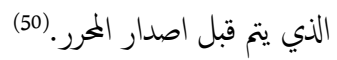
وفيما يلي نعرض طرق التزوير المادي الكلي والجزئي في الفقرات التالية:

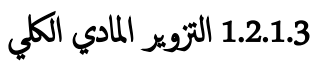
ويتم اختراق وثائق السفر عن طريق التزوير المادي الكلي باحدى الوسائل الاتية:

1.1.2.1.3 الاستيلاء على نماذج صحيحة للوثيقة

يجدث هذه الاستيلاء في مرحلين: أ- مرحلة صناعة الورقة والطباعة :قد يتم الاستيلاء على نماذج وثائق السفر الخام المطبوعة من اماكن طباعتها، او من مراكر اصدارها بمعرفة بجات غير مشروعة متخصصة في ذلك، وتبقى تممة سهلة بعد هذه المرحلة وهي تعبئة الوثيقة بالبيانات الشخصية والتنظيمة بالاسلوب والطريق التي تنهجها عادة جمات الاصدار الرسمية. (51) ب- مرحلة الاصدار: حيث يلجا المزورون الى الحصول على وثائق السفر من جهات اصدارها، حيث يكن استخدام وثائق السفر المزورة سواء عن طريق تزوير الوثيقة نفها او احد بياناها، عند اصدار وثيقة السفر من قبل الموظف او الجهة المختصة استنادا على اوراق وبيانات مزورة، او تغيير في بيانات تحقيق الشخصية او الجنسية، وغالبا ما يتم ذلك بمعرفة الموظف المختص او اشتراكه في التزوير وهو يعلم بامر تزويرها.(52)(

2.1.2.1.3 اصطناع وثيقة سفر جديدة ويعد هذا النوع من اخطر انواع التزوير، حيث يصطنع وثيقة سفر جديد باكملها وهي عادة ما تقع بنعل دول او جاعات، ولتحقيق اغراض غير مشروعة او قد ترنكبه وكلات متخصصة في السفر لغايات الاتجار والربح غير المشروع، حيث يتم اصطناع وثيقة سفر بالشكل والحجم الذي تطبع منه وثائق السفر الصحيحة 


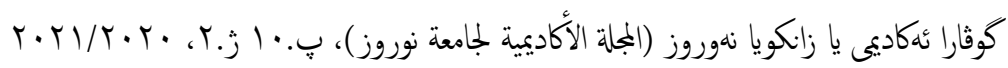

ويجب ان يكون الورقن نوع الجيد، مع اضافة معالجات لعجينة الورق مثل

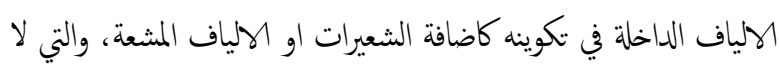
تظهر الا تحت الاشعة فوق البنفجية او الاشعة تحت الممراء او اضافة الالياف الحريرية التي لا تظهر الا تحت الجمهر او تواجد خيط معدني داخل عجينة الورق او يكون هذا الخيط من الحرير (Metal thread) (57)(مثلا او خيط مصنوع من البولي ايستر. (Silk thread) ب. غلاف وثيقة السفر: يجب ان يتصف غلاف جواز السفر بدرجة تحمل عالية، تقاوم ظروف الثداول وظرف استخدامه سواء من صاحبه او من الجهات المعنية، ويجب ان يكون غلاف الجواز مناسبا لما يجتويه ويكون لونه ثابت مقاوم للعوامل المختلفة، كما يجب ان يكون تصميم غلاف جواز السفر واختيار مادته والرسومات والاشكال المرسومة عليه على سطح الغلاف الخارجي او الداخلي من الضانات الامنية التي يصعب عملية اصطناع وثيقة سفر، كما يجب ترقيم الصفحات وثيقة السفر بالرقز

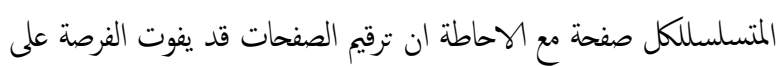
محاولات التزوير، او اضافة صفحات الى محتويات وثيقة السفر ويعتبر رقز وثيقة السفر من الامور التنظيمة في مكتويات التي لها دلالاتمعينة لدى الجهات المعينة او لدى الجهات الامنية، ويتم ترقيم جواز السفر باستخدام نظام التثقبب المرئي بالاضافة الى نظام الترقيم السري الذي يشاهد عند

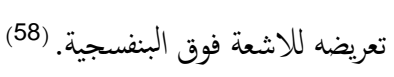

2.1.2.3 تامين مواد وبيانات الوثيقة

تختلف من دول الى اخرى، اساليب تعبئة بيانات تحقيق الشخصية والبيانات

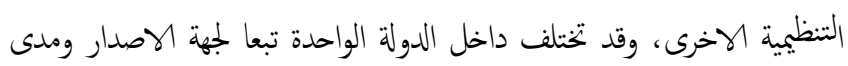
توافر التجهيزات الفنية فيها الو ان هناك بعض البيانات التي لا يكن الو تكون بخط اليد لوتوقيع حامل الجواز. والتزوير يكون اكثر صعوبة على المواد المطبوعة او المكتوبة على الالة الكومبيوتر ، مع العلم انها ليست بمناى عن التزوير والتقليد، لذا فانه يجب حاية المواد المطبوعة

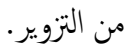
تعد جوازات السفر خير بجال لاظهار افضل ما توصلت اليه وسائل الطباعة الحديثة من فن وروعة وقد كان للتقدم الهائل الذي حققته الطباعة في الوقت الحالي الفضل في اعتاد وسائل الطباعة الحديثة لوسائل المماية الامنية لجوازات السفر ضد التزوير.
حيث يحدث التزوير المعنوي عن طريق الادلاء بمعلومات غير صحيحة للموظف في جهة رسمية او عن طريق تقديم مستندات مزورة يتم بناء عليها اصدار جواز سفر المزور تزويرا معنويا، على وفق ما نصت عليه قانون عقوبات العراقي في الفقرة الثانية من المادة 287 كما وردناها سابقا. 2.3 المطلب الثاني: عناصر ثامين جواز السفر يتم حاية الوثيقة باعتماد خصائص واضحة في الوثيقة الصحيحة، يصعب تقليدها ووضع مجموعة من الاشارات ذات ميزات فريدة وحساسة يصعب تقليدها بمتمعة، وبتغير مظهرها عند محاولة العبث بها. نتناول في هذا المطلب عناصر تامين جواز السفر من اوراق وبيانات ومواد، وكذلك وسائل المماية بالقياسات الحيوية، اضافة الى قياسات منظمة العالمية

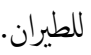
- - - - الفرع الوول: التامين بالقياسات الفنية - الفرع الثالث: التامين بالقياسات منظمة العالمية للطيران المدني ICAO 1.2.3 الفرع الاول: التامين بالقياسات الفنية توجد عناصر عدة لنامين جواز السفر بالقياسات الفنية من اوراق وبيانات ومواد، لذلك نتناول هنا تامين الورق وتامين المواد والبيانات التي يحتوها جواز السفر في

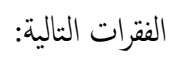
هنالك عناصر عدة لتامين وثائق السفر من اوراق وبيانات ومواد وهي:

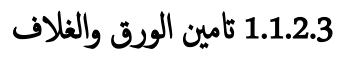
أ. تامين الورق: تضنع اوراق جوازات السفر في الغالب من عينة مكونة من انواع راقية من الالياف السيلولوزية المصنعة من مواد نباتية مختلفة كالكنان، والقطن ، والخنب، وقد ادخلت الان بعض المواد الصناعية الاخرى التي تسامي في الحد من الاختراق.(56) لابد ان يتمز ورق صفحات جواز السفر من اهم عناصر التامين، فالتريكب العنصري لمادة الورق الذي تصنع منه صفحات وثائق السفر، يتطلب بالضرورة وجود تنسيق مسبق مع الجهات المعينة سواء كانت جهة صانعة او طابعة، والا يكون التزيب معلوما الها للجهة المعنية وحسب المواصفات التي تطرحما لجنة التصميم، وخاضعا للرقابة المشددة عند صنع جينة الورق. 


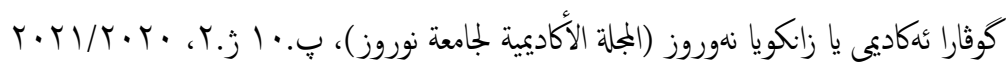

هذه الخطوط وتتلوى وتتفرع فروع، لتاخذ في النهاية وفي كل شخص شكلا ميميزا، وقد ثبت انه لا يكن للبصمة ان تتطابق و تتاثل في شخصين في العالم حتى التوائم الممثاثلة. والبصات تحمل معنى العصمة عن الخطأ في تجديد هوية الشخص لان ترتيب النقش في كل اصبع عند كل انسان ليس له مثيل و لا بتغير مع النمو وتقدم السن، ولهذا تاتي اهمية استخدام البصمة في جوازات السفر الاككتونية كون البصمة لا تتفق في شخصين. ثانيا: بصمة العين: ان لغة العيون تتسع يوما بعد يوم ولم يعد التغني بجالها فقط هو ما يميزها فالعالم الان يتجه الى استخدام بصمة (قزحية العين) في جميع مؤسساته في بنوك ومطارات وكذلك السجون. و القزحية هي الجزء الدائري الملون في العين، والذي ما يكون لونه ازرق او بنيا ويحيط ببؤبؤ العين وهذا الجزء الدائري هو الذي يتحكم في نسبة الضوء الذي يدخل العين عن طريق فتح الحدق وضمها بواسطة عضلة قابضة تتحكم في حجم حدق العين فتسمح لمزيد من الضوء بالدخول للعين عندما يكون المكان منيرا. وان التعرف على البصمة القزحية للشخص لا ياخذ الا ثواني معدودة كما ان تسجيل البصمة لاول مرة لا يأخذ اكثر من ثلاث دقائق بل اقل، والنظارات والعدسات اللاصقة حتى الملونة منها لا تؤثر على المسح شكل القزحية، وهنا التقاط صورة العين لا يتطلب ملامسة الجهاز، كما هو الحال في قراءة البصمة اليد، فقزحية العين هي اكثر دقة وبساطة وخوصوصية فيستحيل فيه اي نوع من التقليد. (61) ثالثا: بصمة الاصوات: يحدث الصوت في الانسان نتيجة اهتزاز الاوتار الصوتية في الحنجرة بفعل هواء الزفير بمساعدة العضلات المجاورة التي تحيط هها تسعة غضاريف صغيرة تشترك جميعها مع الشفاه واللسان والحنجرة لتخرج برة صوتية تيز الانسان عن غيره، والاصوات كالبصات لا تتطابق فكل منا يولد بصمة فريدة مختلفة عن الاخر، وبدأ ابهزة الثرطة في الاستفادة بذبذبات الصوت للكثف عن المجرمين وخاصة في حالات

$$
\text { البلاغات الجمهولة التي تتم عن طرق الهاتف.(62) }
$$

رابعا: بصمة الكف: بصمة الكف عبارة عن خطوط بارزة في بشرة الجلد تجاورها منخفظات وتعلو الخطوط البارزة فتحات للمسام العرقية، وتتادى هذه الخطوط وتتلوى وتتفرع منها وفروع لتاخذ في النهاية شكلا ميمزا، وبصمة الكف لا تتطابق و لاتتماثل في شخصين مختلفين حتى في التوائم.
ومن التقنيات الحديثة في الطباعة هي استخدام وسائل متعددة للطباعة الهنية مثل الطباعة البارزة (سطح غائر)، والطباعة الغائرة (سطح بارز)، والطباعة السطحية (سطح مستوى)، وهناك طباعة مجهرية (سطح غائر)، مع استخدام الخطوط بالكنابة الممنطة على اطراف الوثيقة لتجنب قص الوثيقة او تغيير

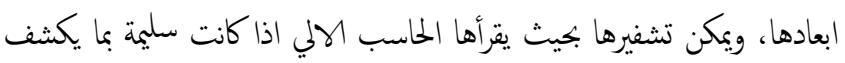
اي خلل فيها.

\section{- 3.1.2.3 تامين طباعة صورة الرقية}

ان اغلب ما يتعرض للتوزير في جوازات السفر هو الصورة والبيانات الاساسية الخاصة بحاملي جواز السفر، لذلك تخرص معظم دول العالم على حهيتها بوسائل تقنية حديثة للحد من العبث والتزوير بها وحايتها وتختلف وحايتها، وتختلف وسائل المماية الامنية للصورة، فقد تطورت عملية تثبيت صورة حامل جواز الصور التي كانت تلصق في السابق بالصورة الرقية الحديثة التي تطبع على صفحات البيانات الاساسية بوسائل الطباعة الرقية، كما تم تضمين الجواز بصورة الظل لصاحها وتكون مماثلة للصورة على جواز السفر، ويعتبر الفليم اللاصق من افضل وسائل المماية التي تم تطويرها لماية البيانات الاساسية الخاصة بحامل جواز السفر وهي عبارة غلاف بلاستيكي رقيق يتم الصاقه على الصفحة المحتوية على الصورة والبيانات الاساسية لحاملها بواسطة بهاز حراري خاص.(59) حيث يتم تثبيت الصورة بطريقة يستحال نزعها، لالصاق صورة اخرى بدلا منها ويتم تغليف الصورة الفوتوغرافية بالاغشية اذا ما حاول المزور نزعها، وتتغير طبيعة الاغثية الشفافة اذا انتزت لاستبدال الصورة التي تتها، كما تحتوي الاغنشية على مواد تتفاعل مع الياف الورق مما يسبب تمزق الورق عند محاولة نزع الغشاء او تصوير او طبع الصورة على الجواز. (60) 2.2.3 الفرع الثاني: التامين بالقياسات الحيوية على الرغز من ان الله سبحانه وتعلى خلق الناس جميعا مشتركين في وحدة الخلق

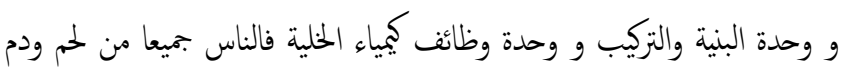
وغظم اصلهم جميعا من تراب، ومع هذا التطابق والتشابه في الخلق والصوت وشكل العظم والرائحة فقد انفرد كل منا في تفاعله الكيموي مع نفسه، لينفرد ببصاته التي يحملها وحده دون سائر البشر. اولا: بصمة الاصابع: بصمة الاصبع هي خطوط بارزة في بشرة الجلد

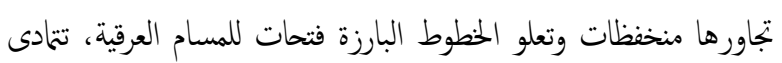




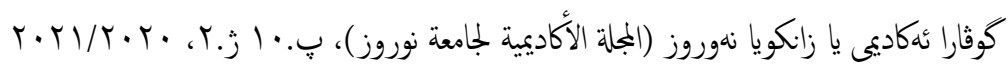

وان منظمة الايكاو (ICAO) قد وضعت المواصفات الفنية القياسية الخاصة بجوازات السفر المقروء اليا، اللازمة لتشغيلها بصورة متبادلة عالميا، وقد اوصت على انه يجب ان تكون المقايس الاسمية لصفحة البيانات في جواز السفر المقروءة اليا، يجب ان نكون 8880 ملم*125، وان سمك صفحة البيانات في جواز السفر المقروء اليا، يجب ان يكون السمك مابين الحد الادني (0.25) ملم ال الحد الاقصى (0.90) ملم. ومن الجدير بالذكر ان المقاييس المحددة لجواز المقرةء اليا، اصغر من مقاييس الجيل السابق، ونتيجة لذلك فقد يتعذر ختم بعض التاشيرات الكبيرة على الصفحات صغيرة الحجم في جواز السفر الجديد، وفي هذه الحالات يمكن ختم التاشيرة على صفحتين متجاورتين في دفتر الجواز المفتوح مع التاكيد من ان دفتز منبسط حتى يككن طبع التاشيرة بشكل مقروء. (67) ومن الجدير بالذكر ان استخدام التكنولوجيا البيومترية في وثائق السفر لاغراض التحقق من الهوية بمساعدة الالات، احد جوانب الاستراتيجية التي تطبقها الايكاو لتحسين عمليات السفر على الحدود بوثائق السفر الجديدة والتكنولوجيا المرتبطة بها، بالاضافة حث قرار الجمعية العمومية للايكلو رق 18-32 A والمحدث في عام ذلك (2001) الدول المتعاقدة على تكثيف بجودها للحفاظ على امن وسلامة جوازاتها، وحاية هذه الجوازات من التزوير، ومساعدة بعضها البعض في هذه المسائل. (68) وان سلامة الجوازات من العوامل الهامة في امن شبكة السفر العالمية، كما ان الثقة في سلامة وثائق السفر الصادرة عن الدول، من جانب سلطات مراقبة

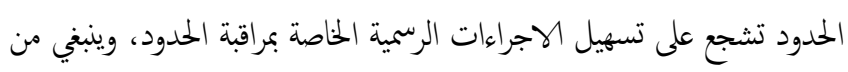

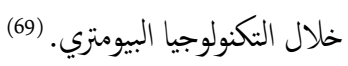
واخير من الجدير بالذكر، التدريب من الوسائل التي تساعد على التقليل من جريمة التزوير والاختاق وهو من الوسائل الفعالة في كثف التزوير حيث تقوم الجهة المختصة بالتدريب بتعريف العاملين بأساليب ووسائل التزوير وطرق كثفها ويشمل التدريب النعرف على مواصفات جواز السفر وما يتضمنه من علامات

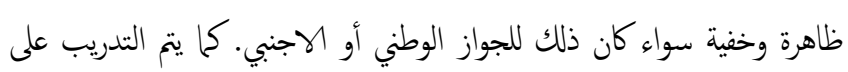
اجراء المقارنة بين الجواز الصحيح من واقع المعلومات التي تدون عليه والعلامات الخاصة وبين الوثيقة المزورة من حيث الشكل العام ومواقع التزوير متزويد العاملين في المنافذ الدخول بكل ما يستجد من أساليب حديثة في مجال تزوير الجواز.
حيث ان بصمة الكف تحمل معنى العصمة في تحديد هوية الشخص لان ترتيب الحزور في الكف عندكل انسان ليس له مثيل و لايتغير مع النمو وتقدم السن. (63) - (63) وخيرا نقول لكي تكون وسائل تامين الوثائق فعالة، لابد ان تكون وسائل كثف التزوير متاحة ومكنة ومتوافرة في البلد الذي يتم تداول الوثيقة فهها، ويلجا الافراد عادة المى تزوير جواز السفر، لتحقيق منفعة لمم من استعال جواز سفر المزورة او المزيفة وكلما كانت هذه المنغعة كبيرة كان الدافع الى التزوير اكبر.

\section{ICAO 3.2.3 الفرع الثالث: الثامين بالقياسات منظمة العالمية للطيران المدني} ان مسالة تامين جواز السفر لا يقل اهية عن امر تنظمه، وماكان جواز السفر او وثيقة السفر هي الصك الرسمي لمارسة حق السفر والتنقل، ومع تزايد المضطرد في تزوير وثائق السفر وابتكار الجديد وتطوير المتاح في اساليب جرائم تزوير هذه

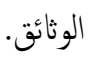

وفي هذه السياق، وضعت منظمة ICAO وفي مجال وثائق السفر في مؤترها اثناء انعقاد الدور الثانية عشر لشعبة تسهيلات النقل الجوي خلال الفترة من

3/22 حتى 2004/4/2، والذي عقد بمركز القاهرة، عدة توصيات منها: (64) تم اتخاذ قرار في هذا المؤتمر بقاعدة قياسية، ملزمة لمجيع الدول مضمونها يجب على الدول المتعاقدة ان تبدأ باصدار جوازات السفر المقروء اليا فقط، وفقا للموصفات المحددة في موعد اقصاه 2010/4/1، كما تم اصدار عدة توصيات مرتبطة بوثائق السفر، منها اصدار الدول وثائق الهوية او التاشيرات المقبولة لاغراض السفر بصورة مقروءة اليا. (65) عدم جواز تجديد صلاحية الجوازات المقروة اليا بالاسلوب اليدوي وباستخدام الاختمام المطاطية، حيث ان ابهزة القراءة الية بالمطارات والمنافذ لن تتمكن من قراءة هذا التجديد، وبتالي ستكون نتيجة قرارة البيانات الاساسية والتي تم تدوينها عند اصدار الجواز تشير الى انتهاء صلاحية الجواز. (66) كما ينصح بالا يتجاوز مدة صلاحية الجواز عن عشرة سنوات، نظرا لنغير مظهر صاحب الجواز مع مرور الوقت. يتعين استخدام التقنيات الحديثة، بالاضافة الى البيانات المقروة اليا، بهدف التاكد على التحقق من هوية حامل جواز السفر والقضاء على

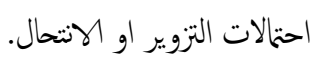




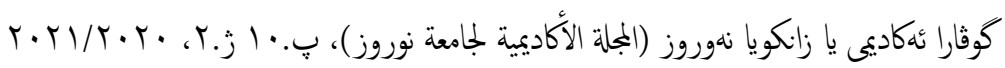

غلاف جواز السفر يجب ان يتصف بدرجة تحمل عالية، تقاوم ظرف

التداول وظرف استخدامه سواء من صاحبه او من الجهات المعنية. وضعت منظمة ICAO وفي مجال وثائق السفر بقاعدة قياسية، ملزمة لجميع الدول مضمونها يجب على الدول المتعاقدة ان تبدأ باصدار جوازات السفر المقروء اليا فقط، وفقا للموصفات المحدة وعدم جواز تجديد صلاحية الجوازات باستخدام الاختمام المطاطية، كما ينصح بالا يتجاوز مدة صلاحية الجواز عن عشرة سنوات، وانها وضعت المواصفات الفنية

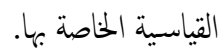

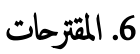

ضرورة اجراء المزيد من المحاية الفنية لجواز السفر وتطويرها باستمرار. تدريب العاملين في مديريات الاقامة والجوازات على كثف اعلال التزوير واطلاعهم على الجديد في مجال الأجزة الحديثة للمساعدة على كشف

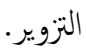

تزويد منافذ الدخول الجوية والبرية بأحدث الأجزة بهدف الكشف على عملية اختراق جواز، و وتحديها هذه الانجزة بصفة دائمة و مستمرة. الاعتماد على استخدام نظام التامين بالقياسات الحيوية توظيفها الكلكتونيا في جوازات السفر وذلك في اثبات الشخصية.

التشديد في عقوبة جرائم التزوير التي تقع جوازات السفر لأهها بالاضافة أن هذه الجرائم تقع على المصلحة العامة في الثقة في المحررات الرسمية كما الها

$$
\text { تسيء المى حق الدولة في اصدار هذه الوثائت. }
$$

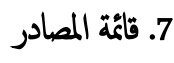
1.7

1. ابراهيم عباس الجبوري، المركز القانوني للاجنبي وفقا لقانون اقامة الاجانب العراقي رخ

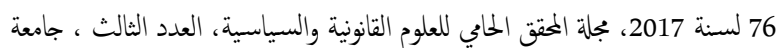

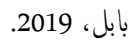
دـ دـ امد محمد امدم مليجي، التنظيم القانون لدخول ومعاملة الاجانب في مصر، اطروحة

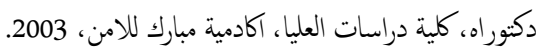

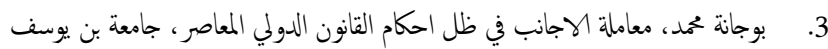

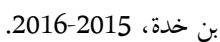
تقرير منظمة الطيران المدني الدولي، وثائق السفر المقروء اليا، (DOC9303) الجزء الاول، الطبعة الخامسة عام 2003. 5. د. حمدي علي عمر، دور القاضي الاداري والدستوري في مجال حاية الاجانب دار النهضة العربية، القاهرة، دمب عرك، دور العاصي

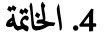
الجوازات السفر من اكثر المررات عرضة للتزوير والتلاعب ببيانها، لذا تحرص معظم دول العالم على صناعة جوازات السفر بمواصفات امنية يصعب على الاشخاص العادين الحصول عليها، من خلال بكثنا في هذا الموضوع وصلنا الىى مجموعة من الاستناجات وفي مقابلها وجدنا أن نوصي بعدة توصيات وهي كما يلي:-

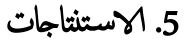

جواز السفر او وثيقة السفر وسيلة اداة لممارسة الفرد حقه في حرية التنقل والاقامة التي حرصت كافة المواثيق الدولية على هذا الحق، والتي بمتضاها تتبين حالة حاملها وشخصيته، بما معنى ان الجواز السفر هي من الوسائل التنظيمة لحق التنقل والاقامة. هنالك اتفاق بين التشريعات المختلفة على اعتبار جواز و وثيقة السفر وثيقة رسمية اساسية صادرة من الجهات الختصة في الدولة، ويشترط لصتها ان يكون ساري المعتول وبخلافه يفقد فعاليها ولا يعتد بها، ان غالبية التشريعات الحديثة تحرص على عدم جواز ادخال الاجنبي اقليم دولتها ما لم يكن حاملا لجواز سفر صادر من السلطات المختصة في دولثه. ان استخراج اكثر من جواز سفر عادي لا تشكل جريمة يعاقب عليها القانون طالما ان البيانات الخاصة باستخراج جواز السفر صحيحة، وعملية استخراج اكثر من جواز سفر عادي صالح في ذات الوقت قد يكون له اكثر من فائدة عملية، من حيث ظروف طارئة تستلزم سفر صاحب الجواز في الحال كظروف صحية عاجلة. وجدنا ان المشرع العراقي والمصري والفرنسي يتفقون على اصدار جوازات السفر العادية والدبلوماسية، اله انهم يختلفون في تنظيم الانواع الاخرى من الجوازات التي تنح لغير الوطني. ان عملية اختراق جواز السفر يتم عن طريق التزوير سواء قد وقع عليها بعد الاستيلاء على نماذج صحيحة او اصطناع وثائق جديدة وقد يقع التزوير بطرق المادية المعنوية على بيانات الشخصية والتنظيمية لجواز. يعتبر الورق الذي تصنع منه وثائق السفر من اهم عناصر التامين، فالتريكب العنصري لمادة الورق الذي تصنع منه صفحات وثائق السفر، وكذلك 


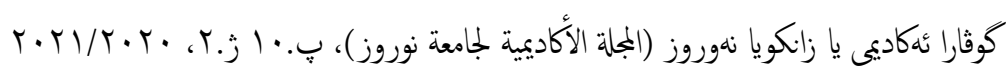

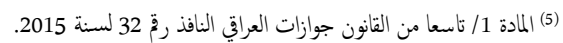

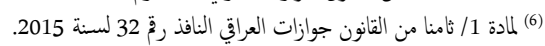

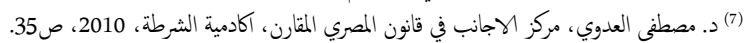

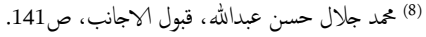

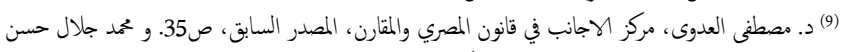

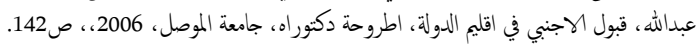

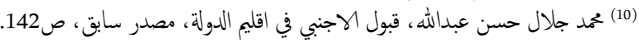

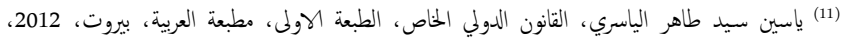

ص355 (12) د. مصطنى العدوى، سلطة الدولة في تنظيم اقامة الاجانب وابعاده والرقابة القضائية عليها، رسالة دكتوراه،

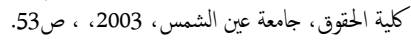
13) د. حمدي علي عمر ، دور القاضي الاداري والدستوري في مجال حاية الاجانب دار النضضة العربية، القاهرة،

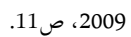

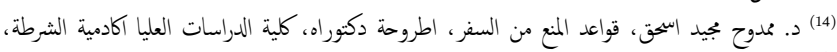

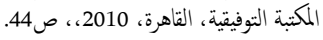

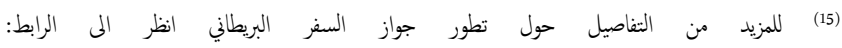
https://assets.publishing.service.gov.uk/government/uploads/system/uploads/attach ment_data/file/258241/passports.pd

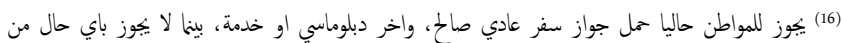

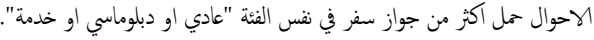

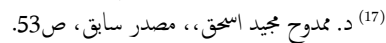

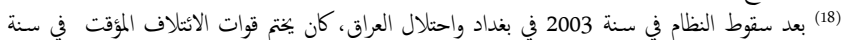

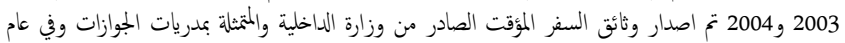

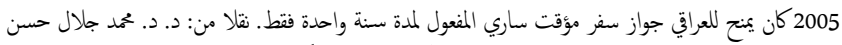

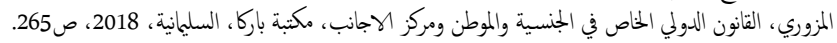

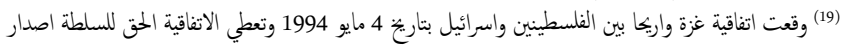

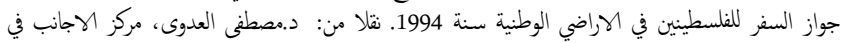

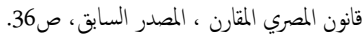

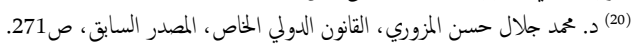

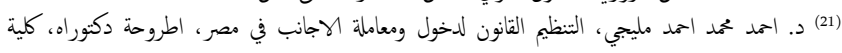

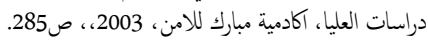

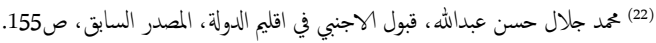

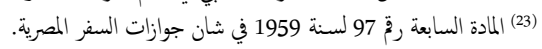

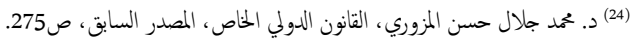

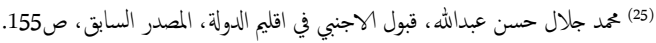

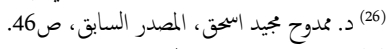

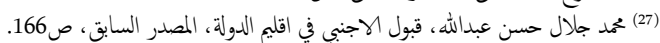

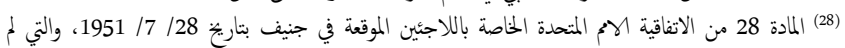
يصادق عليها العراق 20 (29) د. محمد جلال حس المزاف المزوري، القانون الدولي الخاص، ص280.

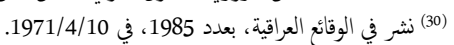

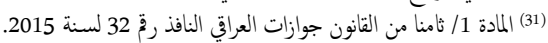

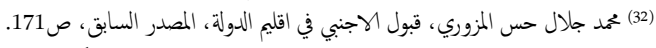

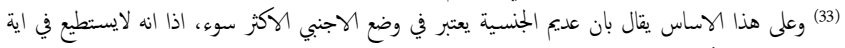

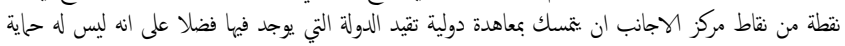

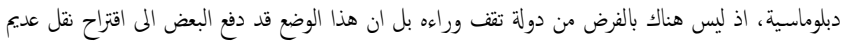

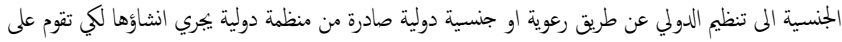

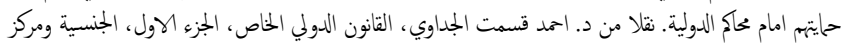

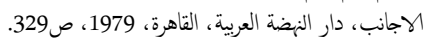

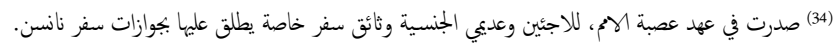

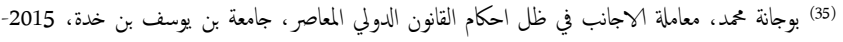

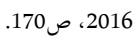

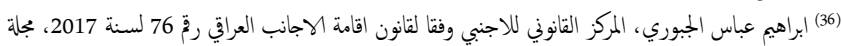

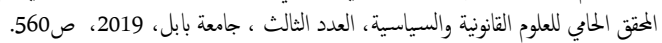

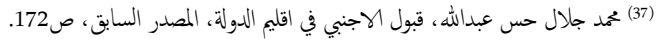

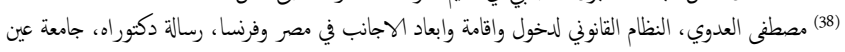

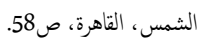

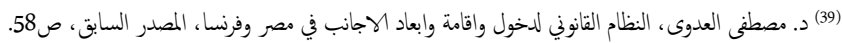

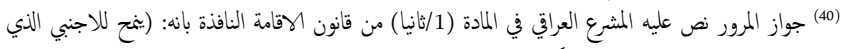

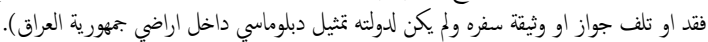

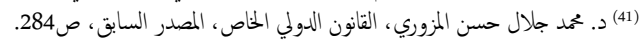

6. د. خالد محمد بجاج، تزوير المحررات في قانون العراقي، مجلة وادي النيل للدراسات

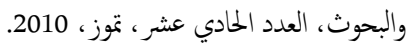
7. زياد زهير احمد الرواشدة، تزوير جوازات السفر و وسائل حايتها، مجلة الامن والحياة،

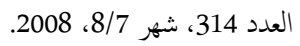

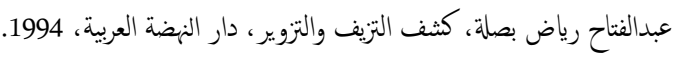

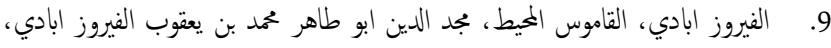

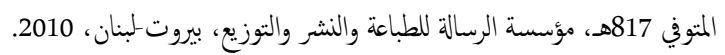

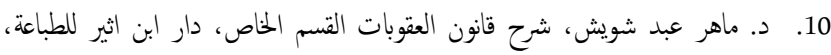
موصل 2005.

11. د. محمد جلال حسن المزوري، القانون الدولي الخاص في الجنسية والموطن ومركز الاجانب، مكنبة باركا، السليمنية، 2018.

12. محمد جلال حسن عبدالله، قبول الاجنبي في اقليم الدولة، اطروحة دكتوراه، جامعة الكانية الموصل، 2006.

13. د. مصطفى العدوى، سلطة الدولة في تنظيم اقامة الاجانب وابعادهم والرقابة القضائية

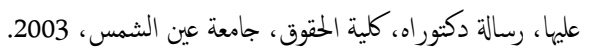

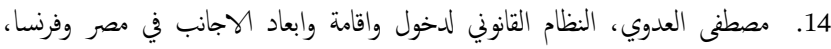
رسالة دكتوراه، جامعة عين الشمس، القاهرة.

15. د. مصطفى العدوي، مركز الاجانب في قانون المصري المقارن، اكادمية الشرطة، .2010

16. د. ممدوح جيد اسحق، قواعد المنع من السفر، اطروحة دكتوراه، كلية الدراسات العليا

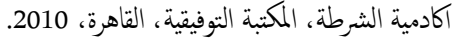

17. ياسين سيد طاهر الياسري، القانون الدولي الخاص، الطبعة الولى، مطبعة العربية، العرة، ببروت، 2012.

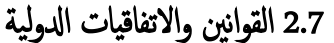

1.

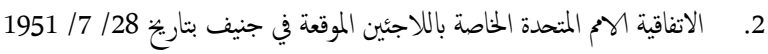
3. نظام جوازات السفر العراقي رق 61 لسنة 1959. 4. قانون رقّ 97 لسنة 1959 في شان جوازات السفر المصرية.

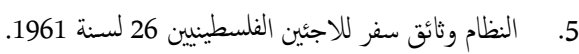
6. قانون العقوبات العراقي رقز 111 لسنة 1969. 7. 8. 9. اتفاقية غزة واريحا بين الفلسطينين واسرائيل بتاريخ 4 مايو 1994.

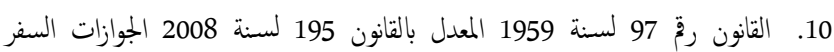
المصري. 11. قانون جوازات السفر العراقي النافذ رقٌ 32 لسنة 2015.

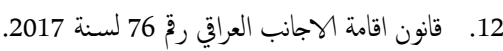

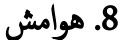

(1) الفيروز ابادي، القاموس الخميط، مجد الدين ابو طاهر محمد بن يعقوب الفيروز ابادي، المتوفي 817هـ، مؤسسة

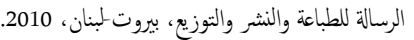
(2) المادة الاولى/سابعا من قانون جوازات السفر العراقي النافذ رخٌ 32 لسنة 2015.

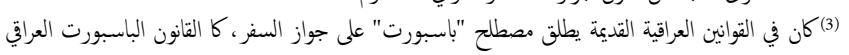

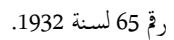
(4) المادة الاولى/ سابعا، من قانون جوازات السفر العراقي رخ 32 لسنة 2015، 2015، المنشور في جريدة الوقائع العراقية: العدد 4381 في 21 اليلول 2015، السنة السابعة والمنسون. 


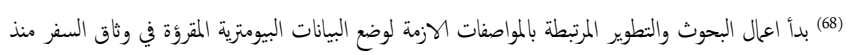

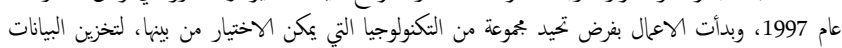

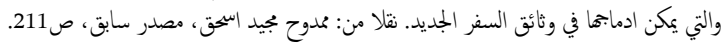

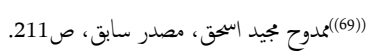

(42) المادة الوولى من نظام وثائق سفر اللاجئين الفلسطينين العدد 26 لسنة 1961. نقلا من: محمد جلال حس

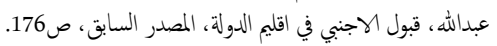
1961/9/11.

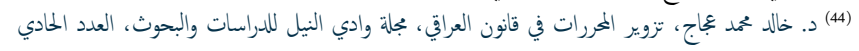

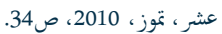

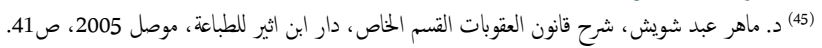

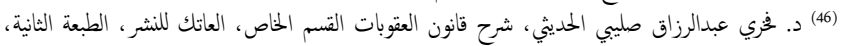

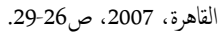

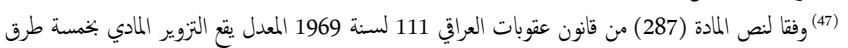

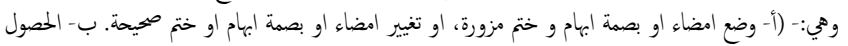

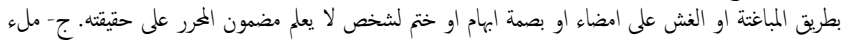

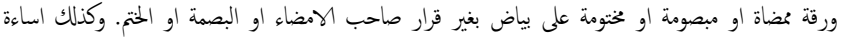

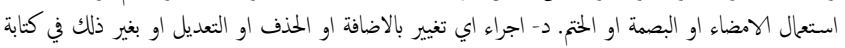

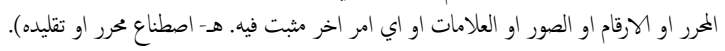

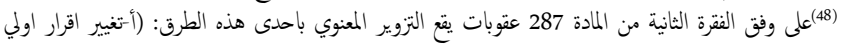

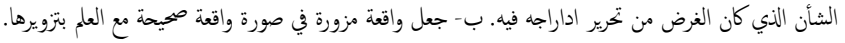

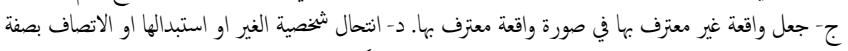

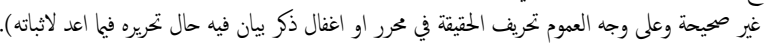

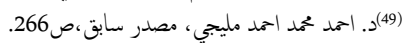

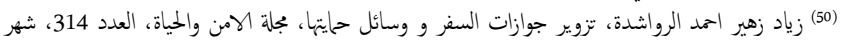

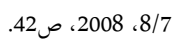

(51)

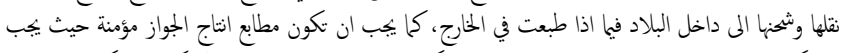

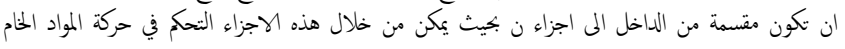

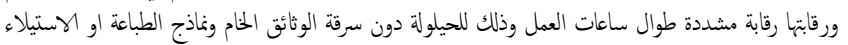

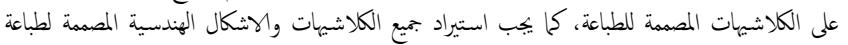

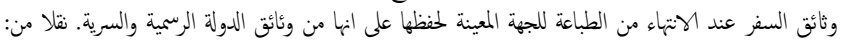

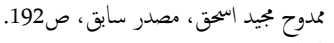

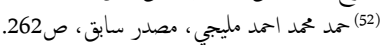
(53)

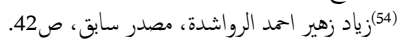

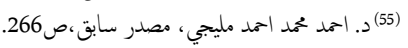

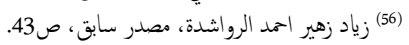

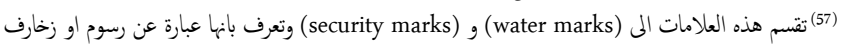

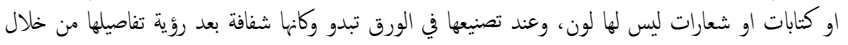

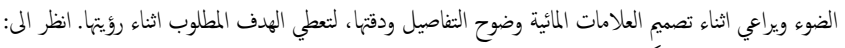

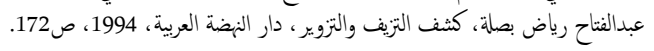

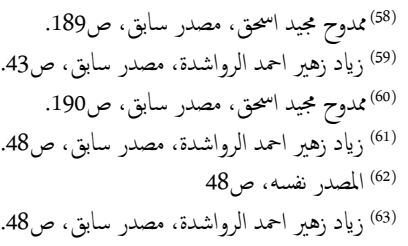

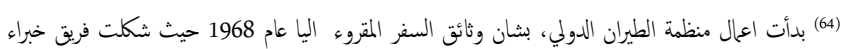

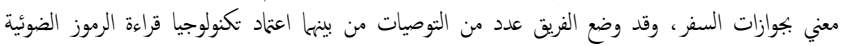

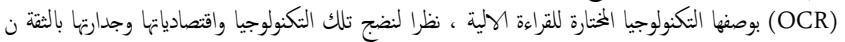

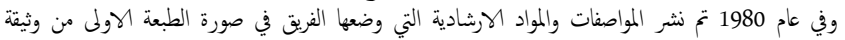

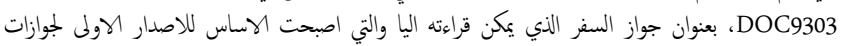

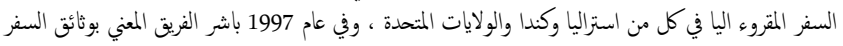

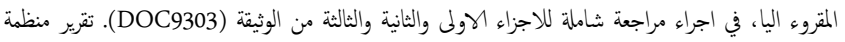

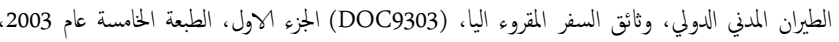

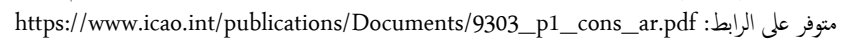

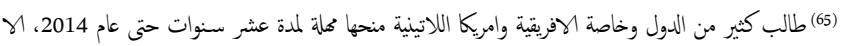

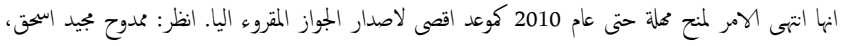

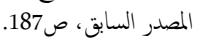

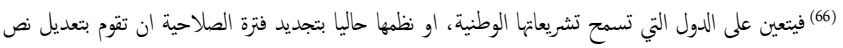
التشريع المعني خلالفنترة زمنية معقولة.

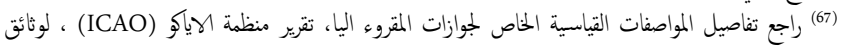

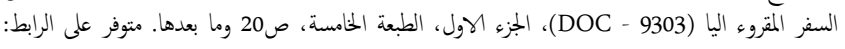
https://www.icao.int/publications/Documents/9303_p1_cons_ar.pdf 